\title{
ANALISIS STRATEGI BISNIS PADA KEDAI KOPI LIMASAN
}

KARAWANG

\author{
Laras Ratu Khalida ${ }^{1}$, Robby Fauji ${ }^{2}$ \\ laras.ratu@ubpkarawang.ac.id \\ robby.fauji@ubpkarawang.ac.id
}

\begin{abstract}
Abstrak
Kedai Kopi Limasan Karawang merupakan sebuah bisnis UMKM di Karawang yang sering dikunjungi oleh anak muda dan para remaja. Tujuan dilakukan penelitian ini adalah untuk mengetahui dan menganalisa strategi bisnis yang ada pada Kedai Kopi Limasan Karawang ini. Metode yang digunakan pada penelitian ini yaitu metode analisis deskriptif kualitatif dan menganalisisnya menggunakan Analisis SWOT. Sumber data yang digunakan dalam penelitian ini yaitu data primer dan sekunder, dimana data primer ini diperoleh dari hasil observasi dan wawancara mendalam (indepth interview) yang berkaitan dengan strategi bisnis pada Kedai Kopi Limasan Karawang terhadap subjek penelitian. Hasil dari analisis SWOT dan Matriks SWOT maka Kedai Kopi Limasan Karawang berada pada Kuadran 1, dimana perusahaan berada dalam situasi yang sangat menguntungkan. Kedai kopi memiliki peluang dan kekuatan sehingga dapat memanfaatkan peluang yang ada. Strategi yang harus diterapkan dalam kondisi ini adalah mendukung kebijakan pertumbuhan yang agresif (Growth oriented strategy)
\end{abstract}

Kata Kunci: Analisis SWOT, Strategi bisnis, Kedai Kopi Limasan Karawang 


\begin{abstract}
The coffee shop Limasan Karawang is a business UMKM in Karawang frequented by a young child and the teenager. The purpose of done this study is to find out and then to analyzed business strategy which is with the coffee shop Limasan Karawang. The methodology that was used to research that is the descriptive qualitatitve and the method of analysis using SWOT Analysis. Data source used in research this is primary and secondary data, where data was obtained from the result of observation and indepth interviews pertaining to business strategy in the coffee shop Limasan Karawang research to the subject. The result of SWOT Analysis and Matrix SWOT so Coffee Shop Limasan Karawang are in Quadrant 1, where the company in the situation extremely fortunate. The coffee shop have a chance and strength that take advantage of opportunities have. Strategy must be applied in this condition is support growth oriented strategy.
\end{abstract}

Key Word : SWOT Analysis, Business Strategy, The Coffee Shop Limasan Karawang 


\section{Latar Belakang}

Perkembangan zaman yang begitu cepat, membuat budaya pun semakin mengikuti zaman nya. Adapun budaya saat ini yang terjadi di kota-kota besar Indonesia yaitu dengan adanya gaya hidup duduk santai di kafe selama berjam-jam bersosialisasi dan berkumpul bersama, yang sudah menjadi tren masyarakat saat ini tanpa disadari hal tersebut merupakan pengaruh dari globalisasi. Menurut Kotler dan Keller (2016:192), gaya hidup adalah pola hidup seseorang di dunia yang diekspresikan dalam aktivitas, minat dan opininya. Gaya hidup menggambarkan keseluruhan diri seseorang dalam berinteraksi dengan lingkunganya. Gaya hidup menggambarkan seluruh pola seseorang dalam beraksi dan berinteraksi di dunia.

Berdasarkan sisi budaya, kafe telah tersebar luas untuk menjadi pusat interaksi sosial dimana orang-orang dapat berkumpul, berbicara, atau sekedar mengisi waktu luang. Masyarakat awalnya mengenal warung kopi sebagai tempat yang relatif sepadan dibandingkan kafe dalam definisi masyarakat barat. Seiring kemajuan teknologi informasi, perkembangan zaman dan asimilasi budaya barat dan lokal, pengusaha warung kopi berkonsep kafe seperti yang ada di barat mulai menjamur. Menurut Nurazizi, 2013), kedai kopi merupakan tempat yang menyediakan kopi beserta produk turunannya sebagai minuman utama dan berbagai jenis minuman (sampingan) lainnya seperti teh dan coklat, selain menyediakan jenis makanan ringan yang juga ditawarkan sebagai kudapan pendamping minum kopi. Kedai kopi juga merupakan tempat berkumpulnya orang-orang yang sekedar bersantai atau melakukan aktifitas (ringan) lainnya seperti diskusi atau obrolan, membaca media cetak, online atau buku, menyelesaikan beberapa tugas akademik atau non-akademik hingga bersenang-senang dengan hiburan yang ditawarkan.

Persaingan dalam dunia bisnis saat ini semakin lama semakin terasa tajam. Para pengusaha dihadapkan pada tantangan yang lebih erat dalam menjalankan usahanya agar dapat bertahan dan mampu mengembangkan usaha yang telah dikelolanya seoptimal mungkin. Oleh karena itu, setiap perusahaan dituntut untuk lebih kreatif dalam memanfaatkan peluang yang ada. Adalah promosi yang merupakan faktor penentu keberhasilan suatu program pemasaran. Betapapun berkualitasnya suatu produk bila konsumen belum pernah mendengarnya dan tidak yakin bahwa produk itu akan berguna bagi mereka, maka mereka tidak akan pernah membelinya (Fandy Tjiptono, 2008:219). Hal ini tentunya menjadi peluang bagi bisnis UMKM dalam mempertahankan bisnis nya.

Kedai Kopi Limasan Karawang merupakan sebuah bisnis UMKM di Karawang yang sering dikunjungi oleh anak muda dan para remaja. Karena segmentasi pasarnya adalah anak muda, maka bisnis kedai atau kafe-kafe merupakan salah satu keuntungan bagi pebisnis untuk saat ini. Walaupun sedang digandrungi oleh para anak-anak muda dan remaja, bukan berarti bisnis kedai kopi ini akan selalu survive, karena begitu banyak bisnis yang bisa meniru kedai-kedai kopi lain, maka sebuah bisnis kedai kopi 
harus bisa melakukan inovasi dan strategi bisnis agar bisa berkembang usaha nya. Sehingga peneliti ingin meneliti lebih dalam mengenai "Analisis Strategi Bisnis pada Kedai Kopi Limasan Karawang".

\section{Rumusan Masalah}

Berdasarkan latar belakang permasalahan di atas maka masalah dapat dirumuskan sebagai berikut :

1.2.1 Bagaimana analisis kekuatan, kelemahan, peluang dan ancaman dari bisnis Kedai Kopi Limasan Karawang?

1.2.2 Bagaimana strategi bisnis pada Kedai Kopi Limasan Karawang?

1.2.3 Bagaimana Matriks SWOT dari bisnis Kedai Kopi Limasan Karawang?

\section{Landasan Teori}

\section{Strategi Bisnis}

Strategi bisnis adalah kemampuan pengusaha/perusahaan dalam analisis lingkungan eksternal dan internal perusahaan, perumusan (formulasi) strategi, pelaksanaan (implementasi) rencana-rencana yang dirancang untuk mencapai sasaransasaran perusahaan, serta melakukan evaluasi untuk mendapatkan umpan balik dalam merumuskan strategi yang akan datang. Variabel ini diukur dengan 3 dimensi yaitu : differentiation, low cost, dan focus strategy. (Mahmud dan Anomsari, 2011:3)

Strategi bisnis merupakan alat untuk mencapai tujuan jangka panjang. Sebuah perusahaan harus berjuang mencapai keuntungan kompetitif secara berkelanjutan, berupa terus beradaptasi untuk berubah dalam eksternal trend dan kapasitas internal, kemampuan dan sumber daya, dan perencanaan efektif, implementasi dan evaluasi strategi yang berperan besar (David, 2011). Joewono (2012:3) mengatakan bahwa strategi bisnis adalah strategi mencapai tujuan yang sering dianalogikan dengan strategi catur, yang dimana sistematika berpikir, penyusunan rencana, kesigapan melangkah, keberanian mengambil resiko dan gairah untuk memenangkan pertandingan merupakan karakteristik permainan catur yang relevan dengan praktek pengelolaan bisnis.

Strategi bisnis yang utama dalam perusahaan adalah bagaimana membangun dan memperbaiki posisi perusahaan dalam persaingan bisnis jangka panjang, adapun 5 prinsip yang harus dipenuhi antara lain:

1. Memberikan jawaban atau reaksi atas perubahan yang sedang terjadi dalam bidang industri perekonomian, politik, hukum dan sebagainya;

2. Berisikan langkah-langkah dan pendekatan untuk menghadapi persaingan;

3. Menciptakan kemampuan dan kesanggupan bersaing yang berkualitas;

4. Menyatakan inisiatif strategi dari tiap departemen fungsional;

5. Menempatkan strategi utama kegiatan operasional perusahaan. 


\section{Analisis SWOT}

Rangkuti (2013:19) mengemukakan bahwa analisis SWOT adalah identifikasi berbagai faktor secara sistematis untuk merumuskan strategi perusahaan. Analisis ini didasarkan pada logika yang dapat memaksimalkan kekuatan (Strength) dan peluang (Oppoturnities), namun secara bersamaan dapat meminimalkan kelemahan (Weakness) dan ancaman (Threats). Proses pengambilan keputusan strategis selalu berkaitan dengan pengembangan misi, tujuan, strategi dan kebijakan perusahaan. Dengan demikian, perencanaan strategis (strategic planner) harus menganalisis faktor-faktor strategi perusahaan (kekuatan, kelemahan, peluang dan ancaman) dalam kondisi yang ada saat ini. Hal ini disebut dengan Analisis Situasi. Model yang paling populer untuk analisis situasi adalah Analisis SWOT.

a) Analisis Lingkungan Eksternal (Peluang dan Ancaman)

Menurut Kotler (2009:51), unit bisnis harus mengamati kekuatan lingkungan makro yang utama dan faktor lingkungan mikro yang signifikan, yang mempengaruhi kemampuannya dalam menghasilkan laba. Unit bisnis harus menetapkan sistem intelijen pemasaran eksternal dan internal. Peluang pemasaran (marketing opportunity) adalah wilayah kebutuhan dan minat pembeli, dimana perusahaan mempunyai probabilitas tinggi untuk memuaskan kebutuhan tersebut dengan menguntungkan. Ancaman lingkungan (environmental threats) adalah tantangan yang ditempatkan oleh tren atau perkembangan yang tidak disukai yang akan menghasilkan penurunan penjualan atau laba akibat tidak adanya tindakan pemasaran defensive.

b) Analisis Lingkungan Internal (Kekuatan dan Kelemahan)

Kemampuan menemukan peluang yang menarik dan kemampuan memanfaatkan peluang tersebut adalah dua hal yang berbeda. Setiap bisnis harus mengevaluasi kekuatan dan kelemahan internalnya.

Analisis SWOT membandingkan antara faktor eksternal Peluang (opportunities) dan Ancaman (threats) dengan faktor internal Kekuatan (strength) dan Kelemahan (weakness). 


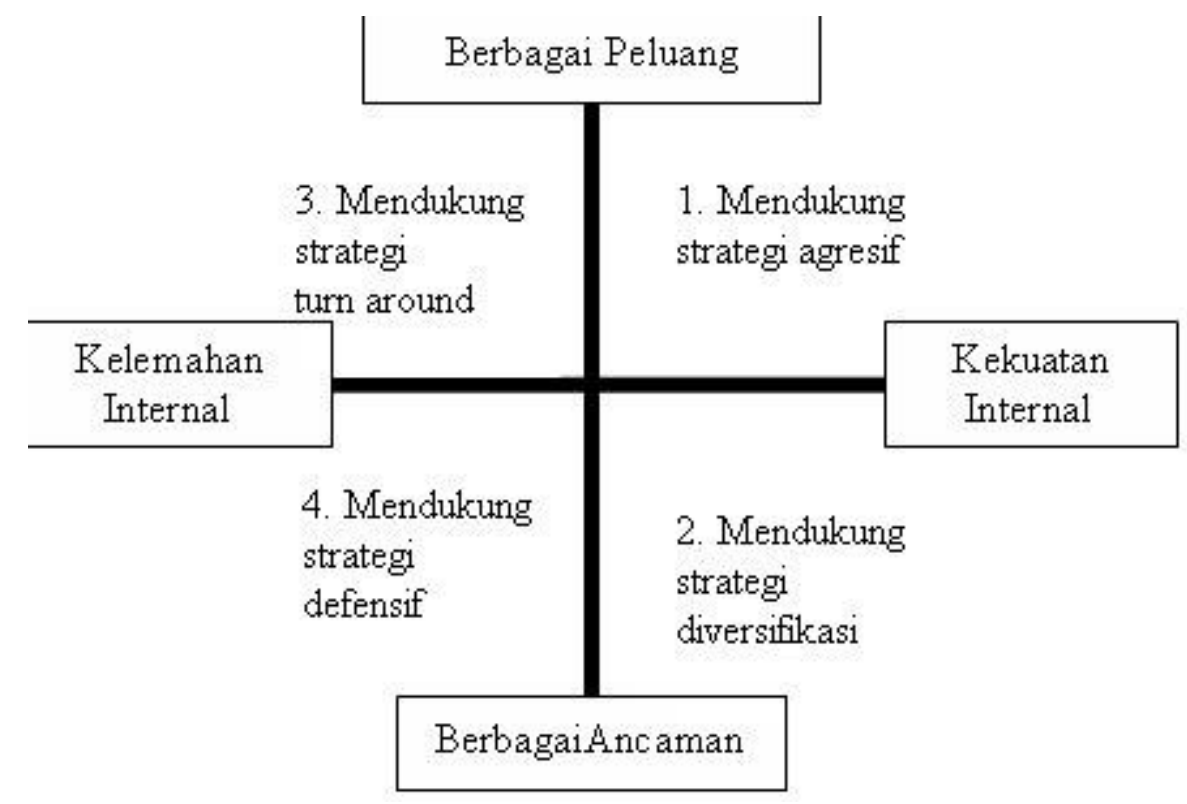

Sumber : Rangkuti (2013:20)

Kuadran $I$ : Ini merupakan situasi yang sangat menguntungkan.

Perusahaan tersebut memiliki peluang dan kekuatan sehingga dapat memanfaatkan yang ada. Strategi yang harus diterapkan dalam kondisi ini adalah mendukung kebijakan pertumbuhan yang agresif (growth oriented strategy).

Kuadran 2 : Meskipun menghadapi berbagai ancaman, perusahaan ini masih memiliki kekuatan dari segi internal. Strategi yang harus diterapkan adalah menggunakan kekuatan untuk memanfaatkan peluang jangka panjang dengan cara strategi diversifikasi (produk/pasar).

Kuadran 3 : Perusahaan menghadapi peluang pasar yang sangat besar, tetapi di lain pihak, ia menghadapi beberapa kendala/kelemahan internal. Kondisi bisnis pada kuadran 3 ini mirip dengan Question Mark pada BCG Matriks. Fokus strategi perusahaan ini adalah meminimalkan masalah-masalah internal perusahaan sehingga dapat merebut peluang pasar yang lebih baik. Misalnya, Apple menggunakan strategi peninjauan kembali teknologi yang dipergunakan dengan cara menawarkan produkproduk baru dalam industry microcomputer.

Kuadran 4 : Ini merupakan situasi yang sangat tidak menguntungkan, perusahaan tersebut menghadapi berbagai ancaman dan kelemahan internal.

\section{Matriks SWOT}

Menurut Umar (2010:86) matriks SWOT dapat menggambarkan bagaimana peluang dan ancaman dari lingkungan eksternal perusahaan diantisipasi dengan kekuatan dan kelemahan yang dimilikinya, matriks ini dapat menghasilkan empat set kemungkinan alternative strategi. Masing-masing alternatif strategi tersebut adalah :

1. Strategi SO (Stratety-Opportunity), strategi ini dibuat berdasarkan jalan pikiran perusahaan, yaitu dengan memanfaatkan seluruh kekuatan yang dimiliki untuk merebut dan memanfaatkan peluang sebesar-besarnya. 
2. Strategi ST (Strength-Threats), strategi ini dibuat berdasarkan kekuatan-kekuatan yang dimiliki perusahaan untuk mengantisipasi ancaman-ancaman yang ada.

3. Strategi WO (Weakness-Opportunity), strategi ini diterapkan berdasarkan pemanfaatan peluang yang ada dengan cara meminimalkan kelemahan yang ada.

4. Strategi WT (Weakness-Threats), strategi ini didasarkan pada kegiatan yang bersifat defensive, berusaha meminimalkan kelemahan-kelemahan perusahaan serta sekaligus menghindari ancaman-ancaman. (David (2010:328)

\section{Metode Penelitian}

Metode yang digunakan pada penelitian ini yaitu metode analisis deskriptif kualitatif dan menganalisisnya menggunakan Analisis SWOT. Sumber data yang digunakan dalam penelitian ini yaitu data primer dan sekunder, dimana data primer ini diperoleh dari hasil observasi dan wawancara mendalam (in-depth interview) yang berkaitan dengan strategi bisnis pada Kedai Kopi Limasan Karawang terhadap subjek penelitian. Dalam menetapkan subjek penelitian ini, penulis menggunakan teknik purposive sampling, karena bisa mendapatkan informasi yang akurat dari narasumber yang memahami pembahasan penelitian sehingga penulis dapat menyajkan data yang kredibel. Sedangkan pada data sekunder didapat dari data sumber pihak lain dengan studi pustaka.

\section{Hasil dan Pembahasan}

\section{Strategi Bisnis Patroli Kopi 3 Karawang}

\section{Strategi Pemasaran}

Strategi bisnis dalam bidang pemasaran yang dilakukan oleh Kedai Kopi Limasan Karawang sebagai berikut :

1. Promosi

Promosi merupakan sebuah upaya perusahaan untuk menyampaikan informasi dari perusahaan tersebut agar konsumen dan masyarakat mengetahui keberadaan, lokasi, produk, serta keunggulan dari produk yang diciptakan oleh perusahaan tersebut. Dalam hal ini, strategi promosi yang sudah dilakukan oleh Kedai Kopi Limasan Karawang yaitu melalui media sosial, personal selling dan Word of Mouth. Namun untuk strategi promosi direct marketing dan public relationship belum diterapkan oleh Kedai Kopi Limasan Karawang.

2. Harga

Harga yang ditetapkan oleh Kedai Kopi Limasan Karawang disesuaikan dengan kantong para pelajar dan mahasiswa, yaitu dari harga minimal Rp. 8.000,- sampai harga maksimal Rp. 23.000,-

3. Produk

Produk-produk utama yang disajikan oleh Kedai Kopi Limasan yaitu macammacam kopi nusantara, dan diminati oleh anak-anak muda. Produk tidak hanya 
didapat saat di Kedai Kopi saja, tetapi bisa diperoleh melalui sebuah platform GoJek yang sudah bermitra dengan Kedai Kopi.

4. Tempat

Dengan bertema gaya klasik khas Jogja yang membuat suasana kedai semakin menjadi tempat favorit para remaja untuk nongkrong. Berlokasi di Jl. Puri Teluk Jambe No.34, Sirnabaya, Kec. Telukjambe Timur, Kabupaten Karawang, Jawa Barat 41361. Letak Kedai Kopi Limasan ini sangat strategis dimana lokasi tersebut dekat dengan sekolah dan kampus, sehingga para pelajar dan mahasiswa dapat dengan mudah mengunjungi dan memilih Kedai Kopi ini sebagai tempat nongkrong.

\section{Strategi Manajemen Sumber Daya Manusia (MSDM)}

Sumber daya manusia sebagai penentu di dalam sebuah organisasi yang mengelola organisasi agar visi misi dan tujuan tercapai. Tenaga kerja yang ada di Kedai Kopi Limasan ada 7 orang. Demi menjaga bisnis nya tetap berkembang dan bertahan hingga saat ini, pemilik memiliki komunikasi yang baik dengan tenaga kerja, agar dapat menciptakan suasana kerja yang baik dan nyaman. Dalam hal perekrutan karyawan di Kedai Kopi Limasan Karawang direkrut oleh pemilik langsung. Tenaga kerja yang direkrut dengan kriteria anak muda yang ingin bekerja, dengan usia sekitar 17 tahun 25 tahun. Kedai Kopi Limasan Karawang mengalami kewalahan dalam melayani konsumen karena keterbatasan konsumen. Sehingga pemilik berencana menambah tenaga kerja di bidang pelayanan.

\section{Strategi Keuangan}

Dengan adanya manajemen keuangan, akan membantu sebuah kedai kopi dalam menyusun kebijakan untuk mengelola keuangan agar tidak terjadi salah kelola. Dalam pengelolaan keuangan, Kedai Kopi Limasan Karawang telah menerapkan dengan baik dalam pencatatan yang rapi seperti laporan laba rugi, laporan keuangan harian dan bulanan, serta memberi upah tenaga kerja sesuai dengan waktunya.

\section{Strategi Produk}

Produksi yaitu suatu proses dimana barang diolah menjadi suatu produk dan dapat menambah nilai guna dan bertujuan untuk memenuhi kebutuhan manusia. Di Kedai Kopi Limasan Karawang, produk yang dijual yaitu macam-macam kopi nusantara yang disajikan dengan beragam macam cara dalam menyuguhkan nya. Produk yang biasa diminati oleh anak-anak muda yaitu kopi tubruk Jawa, kopi v60, Coffee late, latte art. Tak hanya menyajikan kopi saja, tetapi terdapat makanan ringan hingga makanan berat seperti tahu crispy, pizza mie, kentang goreng, sandwich telur, dan nasi goreng. 


\section{Analisis SWOT}

Dari hasil wawancara dengan informan, maka analisis SWOT pada Kedai Kopi Limasan Karawang adalah sebagai berikut :

1. Kekuatan (Strength)

a) Harga yang ditetapkan sesuai dengan kantong para anak muda

b) Lokasi yang strategis karena dekat dengan sekolah dan kampus

c) Tempat yang bernuansa klasik khas Jogja, dan menyajikan suasana yang nyaman

d) Produk yang disajikan sesuai dengan segmentasi pasarnya

e) Pengelolaan manajemen keuangan nya baik

f) Memiliki hubungan yang baik antara pemilik dan tenaga kerja

g) Sudah bermitra dengan Platform Go-Jek

h) Memiliki pelanggan tetap

2. Kelemahan (Weakness)

a) Kurang nya tenaga kerja dalam bidang pelayanan

b) Promosi yang dilakukan belum sepenuhnya dilakukan secara maksimal

3. Peluang (Opportunities)

a) Gaya hidup anak-anak muda dapat menambah minat konsumen

b) Dapat mengembangkan bisnis nya dengan menambah produk baru, dan membuka cabang lain untuk menguasai pasar

c) Memperluas jaringan untuk meningkatkan daya jual beli

d) Melakukan strategi promosi dengan lebih maksimal lagi agar konsumen tertarik.

4. Ancaman ( Threats)

a) Banyaknya pesaing dengan jenis usaha yang sama

b) Tenaga kerja yang begitu muda, sehingga dikhawatirkan labilnya anak muda dapat mempengaruhi sistem organisasi nya

c) Tidak ada kemajuan promosi, sehingga dikhawatirkan penjualan menurun dan tidak ada pembeli yang baru. 


\section{Matriks SWOT}

Tabel 1. Analisis Matriks SWOT

\begin{tabular}{|c|c|c|}
\hline Eksternal & 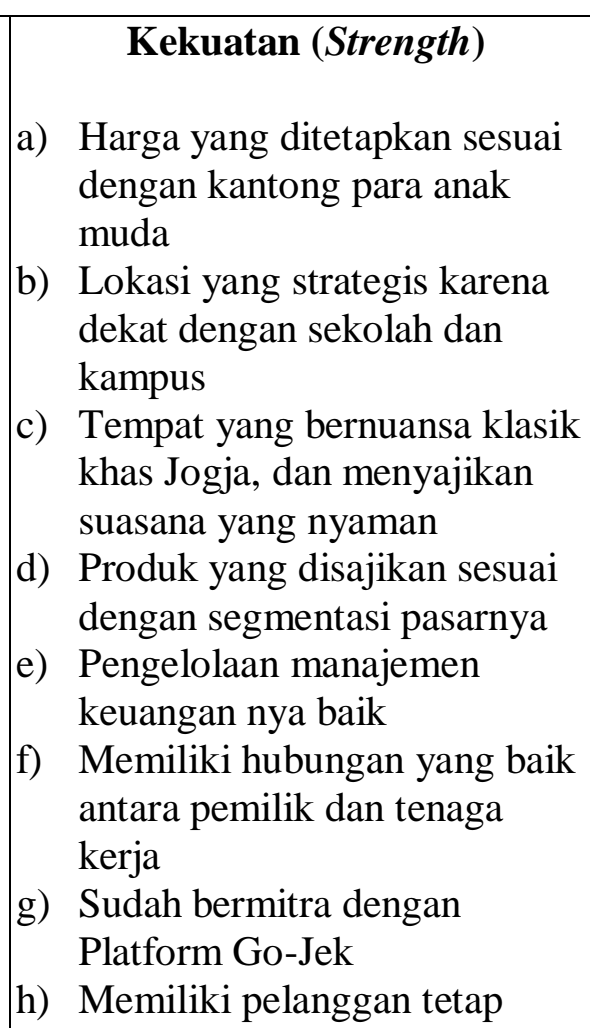 & $\begin{array}{l}\text { Kelemahan (Weakness) } \\
\text { a) Kurang nya tenaga } \\
\text { kerja dalam bidang } \\
\text { pelayanan } \\
\text { b) Promosi yang } \\
\text { dilakukan belum } \\
\text { sepenuhnya dilakukan } \\
\text { secara maksimal }\end{array}$ \\
\hline $\begin{array}{l}\text { Peluang (Opportunities) } \\
\\
\text { a) Gaya hidup anak-anak } \\
\text { muda dapat menambah } \\
\text { minat konsumen } \\
\text { b) Dapat mengembangkan } \\
\text { bisnis nya dengan } \\
\text { menambah produk } \\
\text { baru, dan membuka } \\
\text { cabang lain untuk } \\
\text { menguasai pasar } \\
\text { c) Memperluas jaringan } \\
\text { untuk meningkatkan } \\
\text { daya jual beli } \\
\text { d) Melakukan strategi } \\
\text { promosi dengan lebih } \\
\text { maksimal lagi agar } \\
\text { konsumen tertarik. }\end{array}$ & 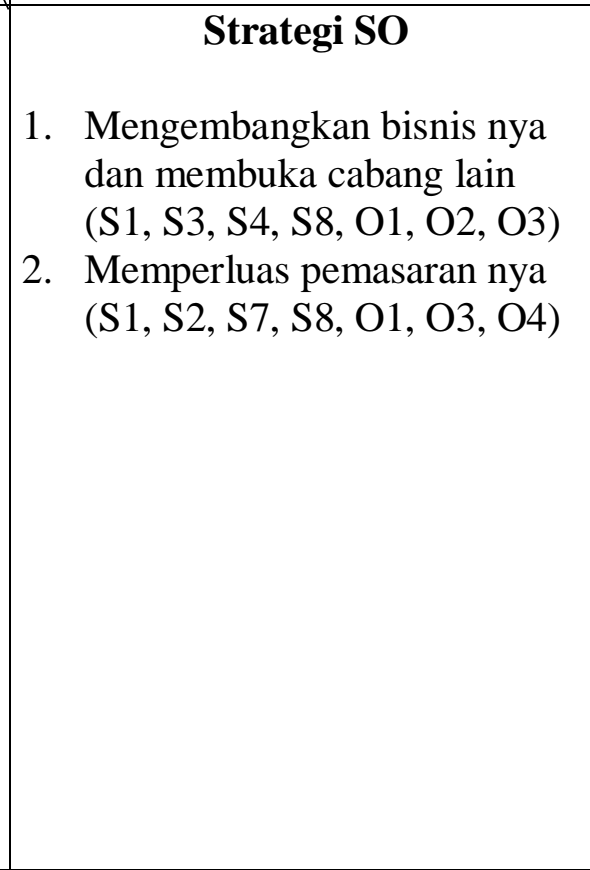 & $\begin{array}{l}\text { Strategi WO } \\
\text { 1. Meningkatkan strategi } \\
\text { promosi (W1, W2, O1, } \\
\text { O3, O4) }\end{array}$ \\
\hline $\begin{array}{l}\text { Ancaman (Threats) } \\
\text { a) Banyaknya pesaing } \\
\text { dengan jenis usaha } \\
\text { yang sama } \\
\text { b) Tenaga kerja yang } \\
\text { begitu muda, sehingga } \\
\text { dikhawatirkan turnover } \\
\text { tenaga kerja } \\
\text { c) Tidak ada kemajuan } \\
\text { promosi, sehingga } \\
\text { dikhawatirkan } \\
\text { penjualan menurun dan } \\
\text { tidak ada pembeli yang } \\
\text { baru. }\end{array}$ & \begin{tabular}{ll} 
& \multicolumn{1}{c}{ Strategi ST } \\
1. & Meningkatkan kualitas \\
produk dan kualitas \\
pelayanan agar konsumen \\
tetap loyal (S1, S4, S8, A1, \\
A3) \\
2. Memberikan pendekatan \\
emosional antara pemilik dan \\
tenaga kerja (S6, A2)
\end{tabular} & $\begin{array}{l}\quad \text { Strategi WT } \\
\text { 1. Meningkatkan promosi } \\
\text { baik untuk produk } \\
\text { maupun promosi } \\
\text { tenaga kerja, agar tidak } \\
\text { terjadi turnover tenaga } \\
\text { kerja (W1, W2, T1, } \\
\text { T2, T3) }\end{array}$ \\
\hline
\end{tabular}




\section{Kesimpulan}

Berdasarkan hasil dari analisis SWOT dan Matriks SWOT maka sesuai dengan teori (Freddy Rangkuti, 2013:20) dimana Kedai Kopi Limasan Karawang jatuh pada Kuadran 1, dimana perusahaan berada dalam situasi yang sangat menguntungkan. Kedai kopi memiliki peluang dan kekuatan sehingga dapat memanfaatkan peluang yang ada. Strategi yang harus diterapkan dalam kondisi ini adalah mendukung kebijakan pertumbuhan yang agresif (Growth oriented strategy)

\section{Saran}

Dari kesimpulan yang didapat dalam penelitian ini, maka terdapat saran-saran sebagai berikut:

1. Kedai Kopi Limasan Karawang dapat mengacu dari kekuatan dan peluang agar dapat mengembangkan produk dan bisnis nya, membuka lagi cabang Kedai Kopi agar pemasaran dan daya jual beli konsumen semakin luas.

2. Dapat lebih meningkatkan strategi promosi nya dengan memperluas jaringan dengan berbagai mitra bisnis.

3. Memperkuat citra merek, memperbaiki kualitas produk dan kualitas pelayanannya agar konsumen tetap loyal.

\section{DAFTAR PUSTAKA}

Kotler, Philip dan Armstrong, Gary. 2012. Prinsip-prinsip Pemasaran. Jakarta: Erlangga.

Mahmud dan Anomsari, Analisis Pengaruh Orientasi Kewirausahaan, Kemampuan Manajemen, dan Strategi Bisnis Dalam Peningkatan Kinerja Perusahaan (Studi Pada Usaha Kecil Menengah di Kawasan Usaha Barito Semarang), Seminar Nasional Teknologi Informasi \& Komunikasi Terapan 2011 (Semantik 2011), 2011, hal. 3.

Tjiptono, Fandy. (2008). Strategi Pemasaran, Edisi 3, ANDI: Yogyakarta.

Freddy Rangkuti. 2013. Riset Pemasaran. Gramedia Pustaka Utama: Jakarta

David, Fred R. 2010. Manajemen Strategis: Konsep (Edisi 10). Salemba Empat. Jakarta.

David, Fred R. 2011. Strategic Management: Concepts and Cases 13th edition. Pearson.

Reza Dwiyan Nurazizi (2013) Kedai Kopi Dan Gaya Hidup Konsumen Simulacrum Jean P Baudrillard Di Excello Malang, Skripsi tidak dipublikasikan. Fakultas Ilmu Sosial Dan Politik jurusan Sosiologi Universitas Brawijaya.

Umar Husein. 2010. Metodologi Penelitian-Aplikasi dalam Pemasaran. PT Gramedia Pustaka : Jakarta

Joewono. 2012. Pengertian perncanaan edisi 12 halaman 3. 